\title{
Correction: Mesenchymal Stem Cells Use in the Treatment of Tendon Disorders: A Systematic Review and Meta-Analysis of Prospective Clinical Studies
}

\author{
Woo Sup Cho, $\mathrm{MD}^{1}$, Sun Gun Chung, $\mathrm{MD}, \mathrm{PhD}^{2}$, Won Kim, $\mathrm{MD}, \mathrm{PhD}^{3}$, \\ Chris H. Jo, MD, $\mathrm{PhD}^{3}$, Shi-Uk Lee, $\mathrm{MD}, \mathrm{PhD}^{4}$, Sang Yoon Lee, $\mathrm{MD}, \mathrm{PhD}^{4}$

\begin{abstract}
'Department of Rehabilitation Medicine, Seoul National University College of Medicine, Seoul National University Hospital, Seoul;
${ }^{2}$ Department of Rehabilitation Medicine, Asan Medical Center, University of Ulsan College of Medicine, Seoul;

${ }^{3}$ Department of Orthopedic Surgery, Seoul National University College of Medicine, SMG-SNU Boramae Medical Center, Seoul;

${ }^{4}$ Department of Rehabilitation Medicine, Seoul National University College of Medicine,
\end{abstract}

SMG-SNU Boramae Medical Center, Seoul, Korea

https://doi.org/10.5535/arm.21078

Ann Rehabil Med 2021;45(4):274-283

After publication of the article, we found the first author name was published incorrectly. "Woo Sup Cho" was changed to "Woosup Cho." The correct author list is:

Woosup Cho, $\mathrm{MD}^{1}$, Sun Gun Chung, $\mathrm{MD}, \mathrm{PhD}^{2}$, Won Kim, $\mathrm{MD}, \mathrm{PhD}^{3}$, Chris H. Jo, $\mathrm{MD}, \mathrm{PhD}^{3}$, Shi-Uk Lee, $\mathrm{MD}, \mathrm{PhD}^{4}$, Sang Yoon Lee, $\mathrm{MD}, \mathrm{PhD}^{4}$

Corresponding author: Sang Yoon Lee

Department of Rehabilitation Medicine, Seoul National University College of Medicine, SMG-SNU Boramae Medical Center, 20 Boramae-ro 5-gil, Dongjak-gu, Seoul 07061, Korea. Tel: +82-2-870-2673, Fax: +82-2-831-0714, E-mail: lsy126@snu.ac.kr

(c) This is an open-access article distributed under the terms of the Creative Commons Attribution Non-Commercial License (http://creativecommons.org/ licenses/by-nc/4.0) which permits unrestricted noncommercial use, distribution, and reproduction in any medium, provided the original work is properly cited. Copyright $\odot 2021$ by Korean Academy of Rehabilitation Medicine 